\title{
İmplant Tanımlama için Katlanmış Dipollü RFID Etiket Anteni Tasarımı
}

\author{
Mahmut Ahmet GÖZEL*1, Mehmet Fatih ÇAĞLAR ${ }^{1}$, Habib DoĞAN² \\ ${ }^{1}$ Süleyman Demirel Üniversitesi, Mühendislik Fakültesi, Elektronik ve Haberleşme Mühendisliği Bölümü, \\ 32260, Isparta \\ ${ }^{2}$ Süleyman Demirel Üniversitesi, Fen Bilimleri Enstitüsü, 32260, Isparta
}

(Alınış / Received: 19.02.2016, Kabul / Accepted: 21.07.2016, Online Yayınlanma / Published Online: 25.08.2016)

Anahtar Kelimeler
İmplant,
Tanımlama,
RFID etiket,
RFID okuyucu,
Anten,
Ortopedik

Anahtar Kelimeler

RFID etiket,

RFID okuyucu,

Ortopedik

\begin{abstract}
Özet: Vücutta eksik ya da fonksiyonunu yapamayan biyolojik dokuların yerini alabilen protez implantlara uygun RFID (Radyo Frekanslı Tanımlama) etiket monte ederek doku üzerinden bilgi alışverişi yapılması günümüz biyoteknolojik çalışmaları arasında yerini almaya başlamıștır. Özellikle ortopedik implant yerleştirme ve değiştirme aşamalarında hasta ve protez bilgisinin implantla birlikte hasta üzerinde taşınması mevcut sistemlere göre maliyet ve zamanı azaltırken, bilgi güvenilirliğini arttıracaktır. Dolayısıyla bu çalışmada, hedeflenen bilgi alışverişini verimli yapabilmek için diz implantı üzerinde çalışabilen ve RFID etiketin en etkili parçası olan anten tasarımı 2,45GHz ISM bandı için irdelenmiştir. Tasarım aşamasında mikroşerit katlanmış dipol anten tercih edilmiş ve özellikle diz implantına yerleştirilebilecek mümkün en küçük ölçülerde gerçekleştirilmiştir. Antenin gerçekleştirilmesi için yaygın FR4 (Fire Resistant 4) taban malzemesi olarak seçilmiştir. Aynı geometriye sahip antenler, ilgili doku ve boş uzay ortamı için sırasıyla modellenmiş ve ölçümleri karşılaştırılmıştır. Ölçüm sonuçlarına göre anten kazancı, bant genişliği ve geri dönüș kaybı değerleri hedeflenen doku ortamı için uygulanabilir bulunmuştur.
\end{abstract}

\section{Folded Dipole RFID Tag Antenna Design for Implant Identification}

Keywords

Implant,

Identification,

RFID tag,

RFID reader,

Antenna,

Orthopedic

\begin{abstract}
Exchange of information by placing suitable RFID (Radio Frequency Identification) tags on prosthetic implant which can replace defective biological tissue in human body, has begun to take its place among today's biotechnological researches. Especially orthopedic implant placement and modification stages, both information of patient and applied implant moves with the patient, while reducing cost and time, improves data reliability according to current systems. So in this study, to achieve efficient target data transmission, design of antenna which is the most critical part of RFID tag and can run on knee implant is studied at $2.45 \mathrm{GHz}$ ISM band. Microstrip folded dipole antenna was preferred in design step and it was realized in the possible smallest size which can be applied on this implant. FR4 (Fire Resistant 4), a common substrate, was chosen for antenna designing and realizing. The antennas having the same geometry were modeled and compared in measurement for related tissue and free space environment respectively. According to measurement results, values of antenna gain, bandwidth and return loss are obtained applicable for target tissue environment.
\end{abstract}

\section{Giriş}

Vücudun kayba uğramış herhangi bir kısmını (organ, doku vb.) yapay olarak tamamlayan, iyileşmesine yardımcı olan ve ilgili doku içerisine yerleștirilen mekanik yapı ve malzemelere implant veya protez adı verilmektedir. Genellikle ağır yaralanmalar ve kazalar neticesinde kalça ve bacaklara yapılan cerrahi müdahalelerde hasarın onarımı için ortopedik implantlar yerleștirmek suretiyle bireyin vücudunu eksiksiz kullanabilmesi hedeflenmektedir. Gelişen teknoloji ile yaygın ulaşım ağının beraberinde getirdiği özellikle ağır iş yükü ve trafik kazaları; bacak ve kalça gibi eklem yerlerinde yıpranma ve yaralanma sayısının artmasına sebep olmaktadır. 
Özellikle bacak ve kalça protezi yerleştirme ameliyatlarının sayısı son yıllarda artış göstermekte ve bu operasyonlara ihtiyacın 2005 ile 2030 yılları arasında sadece Amerika'da 3,48 milyon olacağ tahmin edilmiştir [1]. Cerrahi operasyon gerektiren implant yerleştirme ameliyatlarında cerrah veya doktorların hasta, ameliyat ve implantla ilgili her türlü bilgiye erişimi oldukça önemlidir. Mevcut sistemlerde hastanın, yapılan ameliyatın ve takılan implantın gerekli her türlü bilgisi, hasta kimlik kartlarında, ilgili hastanelerin veri tabanlarında veya arşivlerinde saklanmaktadır. Yani bilgi implant üzerinde değil başka yerlerde depolanmaktadır. İnsan sağlığı gibi önemli bir konuda hasta/ameliyat bilgilerini içeren verilerin kaybolması, çalınması ve sahtekârlık amaçlı değiştirilebilmesi tehlikesinin ortadan kaldırılabilmesi için verilerin implant üzerinde de tahrif edilemeyecek biçimde taşınabilmesi önemli bir çözüm olacaktır. $\mathrm{Bu}$ tip implantların tanımlanması için RFID etiket önerilmesinin birçok önemli sebebi vardır. RFID etiketlere -okuyucu yardımıyla- gerekli veriler hem yazlabilir hem okunabilir olduğundan, RFID etiketli implant, hasta, teşhis ve ameliyatla ilgili tüm gerekli verileri taşıyabilir. Ayrıca çok kısa zamanda veri okunabilir ve tekrar yazllabilir. Hatta veri mahremiyeti olan bölümler gizlenebilir ve şifrelenebilir. En önemlisi de veri sürekli olarak implant içerisinde hazır bulunduğu için bilgi kaybolması veya çalınması gibi endişeler büyük ölçüde giderilebilir. Tüm bu avantajlardan, ortopedik implantların tanımlanması ve takibinde RFID sistem kullanılmasının yarar sağlayacağı ortaya çıkmaktadır.

Temelde RFID sistemi iki ana birimden oluşan bir teknolojidir: RFID etiket ve okuyucu. Etiket, mikroişlemci merkezli alt devrelerin olduğu bir yonga ve antenden meydana gelir. Okuyucu ise bu etiketle elektromanyetik (EM) dalga yayılımı ve kablosuz haberleşme protokolleriyle haberleşen anten, işlemci, alıcl-verici ve bellek devrelerinden oluşur. Ayrıca hem etiket hem de okuyucuyu süren gömülü yazılımlar vardır. Böylece, etiketin bellek kapasitesince taşıdığı özellikleri ve dinamik verileri izleyebilmek mümkündür. Günümüzde RFID kullanım alanı hayal gücü ile sınırlıdır. RFID etiketler türlerine ve uygulama alanlarına göre 64 bit' ten 8MB'a kadar veri depolama özelliğine sahiptirler [2]. İlgili çalışma sektörleri, takip etmek istedikleri nesnelere(ürün, konteyner, kutu/ambalaj, araba, insan, hayvan vb.) uygun RFID etiketleri iliştirerek üzerine bilgi yazabilir, bu yazdığı bilgiyi birkaç santimetrelik mesafeden birkaç yüz metrelik mesafeye kadar okuyabilir. Dolayısıyla RFID etiketler, uygulamanın yapılacağı şartlara göre düşük frekans (LF) 125$134 \mathrm{kHz}$, yüksek frekans (HF) 13,56MHz, ultra yüksek frekans (UHF) $860-960 \mathrm{MHz}$, mikrodalga 2,45GHz, süper yüksek frekans (SHF) $5,8 \mathrm{GHz}$ ve ultra geniş bant (UWB) 3,1-10,6GHz frekanslarında yaygın olarak kullanılmaktadır [3, 4]. RFID sistemlerde en önemli konulardan biri doğru etiketin tasarlanması veya seçimidir. Etiket seçiminde; etiket anteninin boyutları, çalışma frekansı, çalışma koşullarından etkilenmeyecek taban malzemesi seçimi, etiketin uygulandığı yüzeyi kavrama yeteneği, hafıza miktarı ve uygulanacak baskı yöntemi oldukça önemlidir [5].

Çalışmanın nihai ürünü olan hedef RFID etiket anteninin doku ortamında kullanılacak olması implanta yerleştirilecek anten tasarımı konusunda seçici olmayı gerektirmektedir. RFID etiket antenleri aktif, yarı aktif ve pasif olarak sınıflandırılabilir. Aktif RFID etiketleri bir verici ve güç kaynağına sahiptir, güç kaynağı mikro yonganın devrelerini sürerek okuyucuya sinyal gönderilmesini sağlar. Pasif etiketler güç kaynağına sahip olmadıkları için okuyucu devresinden gelen elektromanyetik dalganın enerjisi ile uyarılır. Yarı pasif etiketler ise yonganın devrelerini beslemek için güç kaynağı kullanırken iletişimde aktif olmak için okuyucu devresinden sinyal alırlar. Aktif ve yarı aktif etiketler sürekli veya kısmi zamanlı çalıştıkları için bulundukları ortama göre ısı yaymaktadırlar. Ayrıca bu etiketlerin çalışması için gerekli pil, etiket boyutunu arttırmakta böylece bu tip antenlerin kullanım alanlarını sinırlandırmaktadır. $\mathrm{Bu}$ yüzden ortopedik implantların tanımlanması ve takibinin yapılabilmesi için pasif RFID etiketlerin kullanılması daha uygundur. Pasif etiketler okuyucu antenden yayılan sinyalin gücüne bağlı olarak çalıştıkları için sinyal iletiminin belli seviyede başarılı olabilmesi için anten verimi oldukça önemlidir. Aslında anten verimini arttırabilmek ve etiketi kolayca aktifleştirebilmek için anten boyutunu arttırmak çözümlerden biridir. Fakat gerek implant üzerindeki kısıtlı alan, gerekse anten büyüdükçe okuyucunun EM kapsama alanındaki ışımanın diğer medikal cihazlar ve kalp pili gibi hassas birimlerle etkileșebilmesi hedef anten tasarımını zorlaştırmaktadır [6]. Vücut içerisine yerleștirilen pasif etiket antenlerinin uyarılması, genellikle okuyucu ve etiket anteninin rezonansında endüktif kuplaj (bağlama) metodu ile yapılmıştır [79]. Fakat ortopedik implantların birçoğu iletken metal malzemelerden yapıldığından, iletilmek istenen sinyaller ile etkileşime sebep olmaktadır. Bu yüzden mevcut RFID antenler düșük verimle çalıșmaktadır $[10,11]$. Mevcut RFID sistemlerden farklı olarak, okuyucu anten ile etiket anteni arasında hayvansal doku modeli ve etiketin yerleştirileceği kısım olan diz implantı Şekil 1.' de gösterilmektedir.

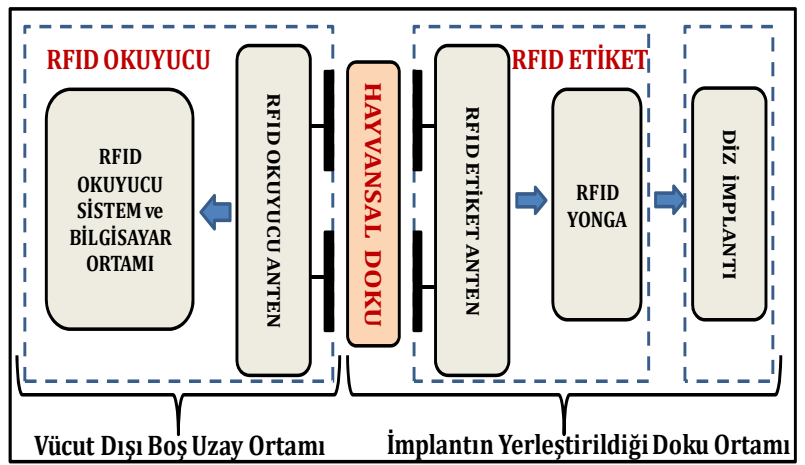

Şekil 1. RFID sistem yapısı 
Burada uygun bir anten bağlanmış mikro yongalı etiket ve antenli bir okuyucu devresi vardir. Okuyucunun verici devresindeki anten EM dalga göndererek etiket antenini uyarır. Pasif RFID etiket antenin konumu, polarizasyona bağlı yönü ve örüntüsü gelen dalgadan enerjiyi en çok alacak şekilde ayarlanmalıdır. Yongayı aktifleştirmek için etiket anten gelen EM dalgadan aldığı gücü yonga girişine aktarır ve yonganın belleğindeki veriler yine etiket anteni ile okuyucuya gönderilir, okuyucu bu verileri alarak bilgisayar ortamına aktarır. Bu temel yapı, insan ve hayvan takibi için deri altına etiket yerleştirmek suretiyle RFID sistemler kullanılarak yapılan çalışmalarda da mevcuttur. $\mathrm{Bu}$ sistemler genellikle otomasyon, eğitim, hazır giyim, gida, lojistik, güvenlik sistemleri ve sağlık alanlarında kullanılmaktadır. Sağlık alanında ise hasta ve bebek takibinde ve kan bankalarında yaygin olarak kullanılmaktadır. [12, 13]. Ayrıca ortopedik implantları RFID ile tanımlama için HF'de ve UHF Gen 2 standartlarında yapılmıș ortopedik diz implantın farklı noktalarına yerleștirilmiş etiket antenlerin farklı çalışma metotları ile performansları değerlendirilmiștir $[8,14-16]$.

$\mathrm{Bu}$ çalışmada, kullanılacak protezin boyutları, RFID etiket yerleștirilebilecek muhtemel yerler ve çalışılması planlanan frekans aralığı dikkate alınarak, farklı anten geometrilere sahip antenler simülasyon ortamında tasarlanmıştır. Bu tasarımlar içerisinden boyutça yüzey alanı en düşük olan katlanmış dipol anten seçilmiştir. Çünkü etiketin boyutça $\% 99$ 'dan fazlasını oluşturacak antenin implantta az yer kaplaması uygulanabilirliğini artıracaktır. Geometriye karar verildikten sonra, aynı geometriye sahip $2,45 \mathrm{GHz}$ merkez frekansı için modellenen ve doku ve boş uzay ortamı için ayrı tasarlanan farklı boyutlardaki iki antenin tasarımlarına ait uzunluk parametre değerleri, geri dönüş kaybı ve ışıma örüntüsü ile ilgili simülasyon ve ölçüm sonuçları elde edilmiştir. Burada, diz implantında kullanılan malzemeler ve doku ortamının, RFID etiket anteninde oluşturacağı girişimi azaltacak şekilde, anten boyutları ve taban malzemesi özellikleri gibi birçok parametre göz önünde bulundurulmuştur. Sonuçta, elde edilen tasarımlar kendi arasında ve daha sonra literatürde benzer amaçla tasarlanmış RFID etiket antenleri ile karşılaştııılmıştır.

\section{Materyal ve Metot}

\subsection{Anten geometrisinin belirlenmesi}

$\mathrm{Bu}$ çalıșma için etiket anteninin çalışma frekansı $2,45 \mathrm{GHz}$ olarak seçilmiştir. Bunun sebebi mevcut RFID etiketlerdeki "Türkiye için UHF bandında ayrılan 865,6-867,6MHz aralığına" göre daha küçük boyutlarda tasarım imkânı sağlayabilmesidir [17, 18]. Ayrica $2,45 \mathrm{GHz}$ merkez frekansinda yapılan çalışma daha geniş bir çalışma bant genişliği sunabilmektedir.
Tasarlanacak antenin, implantın yerleștirileceği doku ortaminda kullanılıyor olması anten boyutunda ve çalışma frekansında dikkatli olmayı gerektirir. Dolayısıyla istenen performansın sağlanması için doğru anten geometrisinin tespit edilmesi önemlidir. Geleneksel RFID etiket anteninin türlerinden [19-21] Şekil 2.' deki kıvrılmış yarık anten, halka yüklemeli mikroşerit dipol anten ve mikroşerit kıvrımlı dipol anten tasarımları denenmiş, fakat bu antenlerin diz implantında uygulanabilir boyutlarda olmadığı tespit edilmiştir.

Şekil 2.' de gösterilen RFID etiket anteni türleri genellikle $840-960 \mathrm{MHz}$ bandında uygulanmaktadır. $\mathrm{Bu}$ antenlerin $2,45 \mathrm{GHz}$ çalışma frekansı için tekrardan tasarlanıp fiziksel büyüklükleri hesaplanmıştır. Tablo 1.' de bu değerler karşılaștırmalı olarak gösterilmektedir.

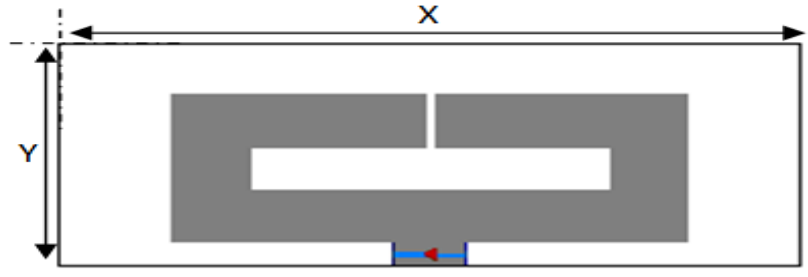

a)Kıvrılmış Yarık

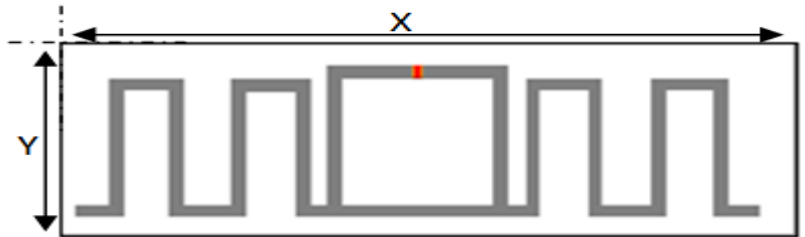

b) Halka yüklemeli mikroşerit dipol

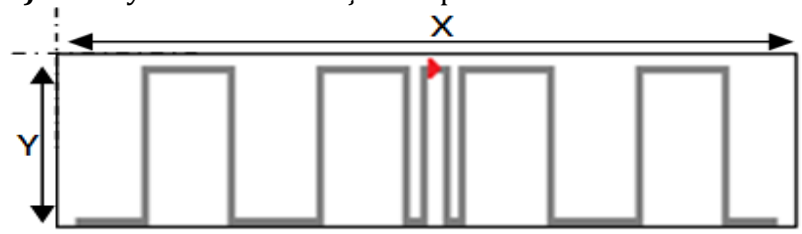

c) Mikroşerit kıvrımlı dipol

Şekil 2. Mevcut RFID etiket anteni türleri

Şekil 3.' deki gibi bir mikroșerit dipol antende $X, Y$ ve $\lambda$ uzunluk hesabı yaparken aşağıdaki formüller kullanılmaktadır [22].

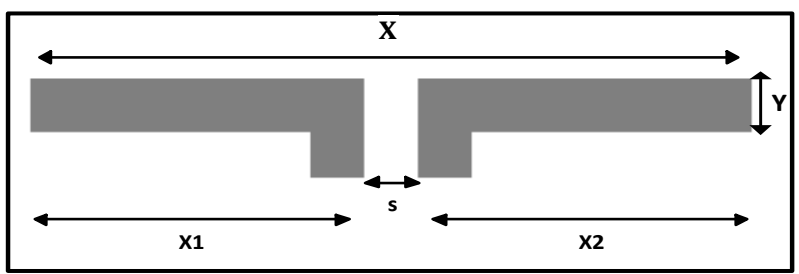

Şekil 3. Bir mikroşerit dipol anten modeli

$$
\begin{gathered}
\varepsilon_{e f f}=\frac{\varepsilon_{r}+1}{2}+\frac{\varepsilon_{r}-1}{2}\left[1+12 \frac{T}{Y}\right]^{-1 / 2} \\
\lambda=\frac{c}{f \sqrt{\varepsilon_{e f f}}}
\end{gathered}
$$


- $\varepsilon_{e f f}=$ Etkin dielektrik sabiti,

- $\varepsilon_{r}=$ Dielektrik sabiti,

- $T=$ Taban malzemesine ait kalınlık,

- $\quad Y=$ Mikroşerit hattın genişliği,

- $\mathrm{f}=$ Çalışma frekansı,

- $\quad c=$ Işık hızı,

- $\lambda=$ Dalga boyunu ifade eder.

Kullanılan taban malzemesinin dielektrik sabiti 3,45, taban malzemesine ait kalınlık 1,48mm, mikroşerit hat genişliği $2,7 \mathrm{~mm}$, olarak alındığında $2,45 \mathrm{GHz}$ merkez frekansı için (1) ve (2) denklemlerine göre dalga boyu 75,45 mm olarak hesap edilir. Şekil 3.' de görülen $X 1=X 2=\lambda / 4$ için $18,86 \mathrm{~mm}$ olarak bulunur. Antenin yerleşeceği implant üzerindeki yeri doğrudan etkileyen uzunluk $X=s+X 1+X 2=s+37,72 \mathrm{~mm}$ olarak hesaplanır ve bu değerin $65 \mathrm{~mm}$ 'den küçük olması gerekir. Çünkü yerleștirilecek yüzeyin kavisli olması sebebiyle bu uzunluğun yaklaşık düz bir yüzey kabul edilebilmesi için daha da kısa olması gerektiği açıktır. Burada s anten tasarım parametresi olarak kullanılabilir. Tablo 1.' den görüleceği üzere bu uzunluk G şeklindeki mikroşerit dipol anten için 28 mm olarak hesaplanmıştır. Tablo 1.' de verilen uzunluk değerlerine bakıldığında mikroșerit dipol antenin, implanta uygulanacak bölge için, Şekil 2.' de gösterilen RFID etiket anten türlerine göre daha az yer kapladığı anlaşılmaktadır. Fakat mikroşerit dipol anten de implant için gerekli boyutların üzerinde değerlere sahiptir.

Boyut problemini çözmek için bazı RFID okuyucu anten tasarımında [23] ve genellikle WLAN mobil iletişim cihazlarının anten tasarımında [24, 25] kullanılan G-şeklinde katlanmış mikroşerit dipol anten tasarlanmasının uygun olduğu belirlenmiştir. Tasarlanmak için seçilen antenin geometrik yapısı Şekil 4.' de gösterilmiştir. Şekil 2.' deki mevcut RFID etiket anteninin türleri ile Şekil 4.' de gösterilen ve bu çalışma için tercih edilen G-şeklindeki katlanmış dipol antenin boyutları Tablo 1.' de karşılaştırılmıştır.

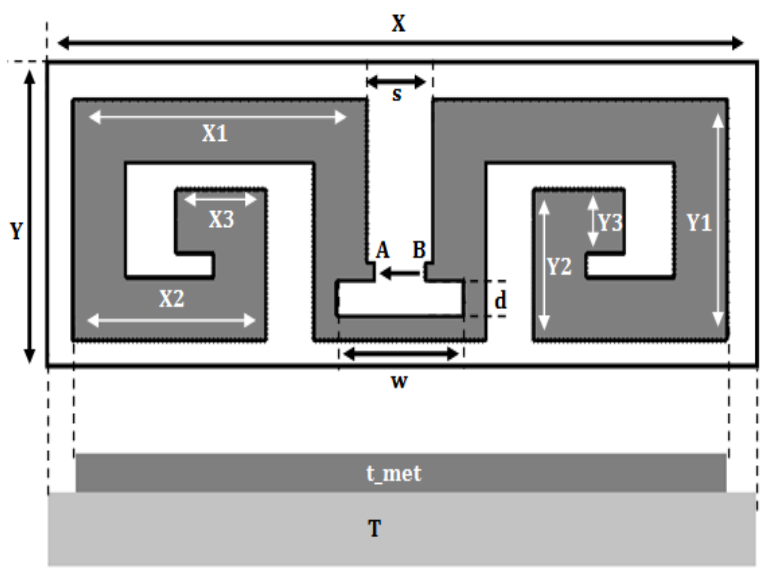

Şekil 4. RFID etiket anteni için önerilen anten geometrisi

Şekil 2. ve Şekil 4.' deki antenlerin fiziksel uzunlukları $X$ ve $Y$ değerleri Tablo 1.' de gösterilmiştir. Tablodan görüleceği üzere, G-şeklinde katlanmış dipol antenin, diğer antenlere göre daha küçük boyutlarda tasarlanabilmesi ve böylece diz implantı üzerine yerleştirilebilmesinin mümkün olduğu anlaşılmaktadır.

Tablo 1. G-şeklindeki etiket anteni ile mevcut RFID etiketlerin karşılaștırılması

\begin{tabular}{ccc}
\hline Anten Türleri & $\boldsymbol{X}[\mathbf{m m}]$ & $\boldsymbol{Y}[\mathbf{m m}]$ \\
\hline G-SSeklindeki Dipol Anten & 28 & 9,15 \\
Mikroșerit Kıvrımlı Dipol & 200 & 10 \\
Halka Yüklemeli Dipol & 96 & 14 \\
Kıvrılmıș Yarık Anten & 150 & 10 \\
\hline
\end{tabular}

\subsection{Antenin yerleştirileceği implant ve doku ortamı}

Vücuda yerleștirilen protez implantlar genellikle titanyum, silikon, hidroksi apatit gibi vücuda uyumlu malzemelerden yapılmaktadır [26]. Böylece implant, eksik olan organın diğer organları etkilemeksizin vücutta daha uzun süre olumlu etkisini gösterebilmektedir.

$\mathrm{Bu}$ çalışmada amaç bir ortopedik implant olan diz protezinin tanımlanması ve kimliklendirilebilmesi için RFID etiket anteni gerçeklemektir. $\mathrm{Bu}$ yüzden RFID etiket antenin, diz imlantında bulunan uyluk kemiğine ait femoral bileșen ile kaval kemiğine bağlı tibial bileșenin arasında bulunan ve bu iki bileșen arasındaki esnekliği ve uyumu sağlayan, genellikle polietilen malzemeden yapılan bileșenin üzerine yerleştirilmesi hedeflenmiştir. Şekil 5.' de bir ortopedik diz implantını olușturan kısımlar ve hedeflenen implant antenin konumu gösterilmiştir. RFID etiket anteninin yerleştirileceği ortam ve konum tasarlanacak antenin veriminde etkili olduğundan, Şekil 5.' de gösterilen ortopedik diz implantını oluşturan kısımlardan polietilen malzemenin dielektrik özellikleri anten tasarım parametrelerini etkilemesi açısından değerlendirilmiştir. Bu uygulamada kullanılacak olan polietilen malzemenin dielektrik sabiti $\varepsilon_{\mathrm{r}}=2,26$, kayıp $\operatorname{tanjantı} \tan \delta=0,00031^{\prime}$ dir.

Anten insan vücuduna yerleştirilerek yüksek oranda kayıplı ve sinyal dağıtıcı ortama girmiş olur. Bu ışıma elemanını çevreleyen kayıplı dokular ve implantı oluşturan malzemeler, anten performansını önemli ölçüde değiştirir. Bu durum antenin elektriksel uzunluğunu değiştirecektir. Sonuç olarak, sabit boyutlar göz önüne alınırsa boş uzay ortam parametrelerine göre tasarlanmış anten, kayıplı ortamda daha düşük rezonans frekansı üretecektir. Doku parametreleri (dielektrik sabiti, iletkenliği ve kütle yoğunluğu) sıcaklık ve frekansa bağlıdır. Biyolojik dokularda frekans artarken dielektrik sabiti düşer ve iletkenlik artar [27]. Kullanılan FR4 taban malzemesi, polietilen malzeme ve doku ortamı dielektriği ele alındığında; etkili ve küçük boyutlu bir etiket anteninin tasarımı, uzunluk parametrelerinin optimum değerleri ile mümkündür.

Sonuçta, ortopedik diz implantında eklem kısmını oluşturan ve antenin yerleştirileceği bölge polietilen 
olduğundan, simülasyonda 3 katmanlı bir model yapı oluşturulmuştur: En üst katmanda deri, hemen altında etiket anteni ve en altta diz implantının eklem kısmını oluşturan polietilen malzeme özellikleri taşıyan katman. Bu model yapı Şekil 6.' da gösterilmiştir.

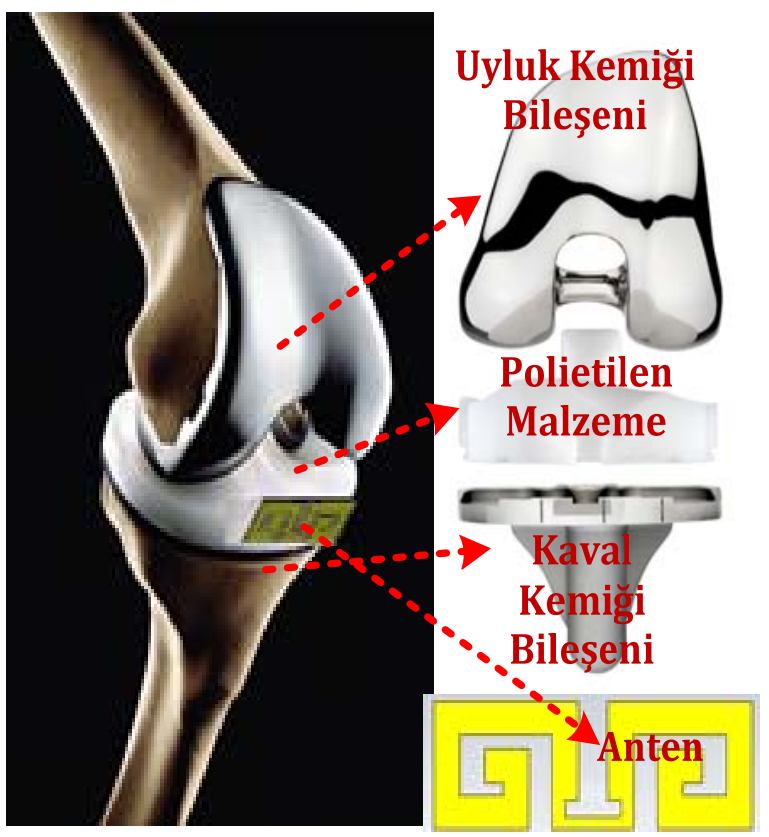

Şekil 5. Bir ortopedik diz implantını oluşturan kısımlar ve antenin hedeflenen konumu

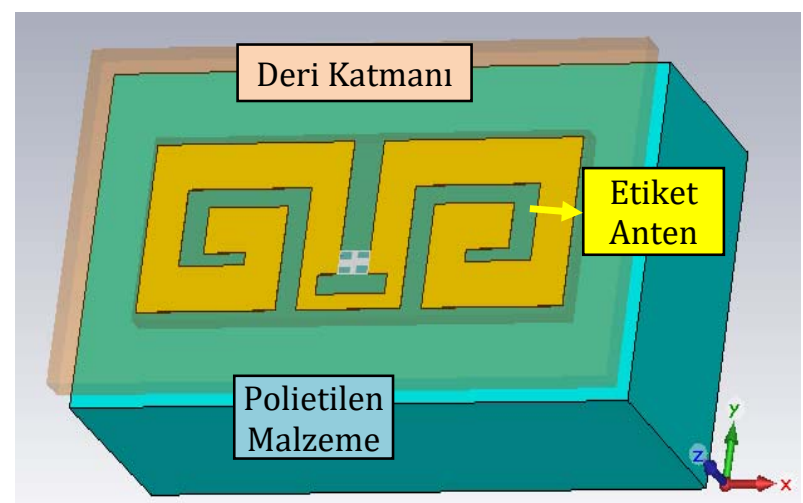

Şekil 6. RFID etiket anteni ve yerleştirildiği ortamın modellenmesi

\section{Bulgular}

Bu bölümde, aynı geometriye sahip 2,45GHz merkez frekansı için modellenip, doku ve boş uzay ortamı için ayrı tasarlanmıș, farklı boyutlardaki iki antenin tasarımlarına ait uzunluk parametre değerleri, geri dönüş kaybı ve ışıma örüntüsü ile ilgili simülasyon ve ölçüm sonuçları verilecektir.

Şekil 4.' deki geometrik yapı için iki farklı anten tasarımı yapılmıştır. Doku içerisinde diz implantına entegre edilecek şekilde modellenen anten Tasarım 1, vücut dışında çalışması planlanan boş uzay ortamı için modellenmiş anten Tasarım 2 diye adlandırılmıştır. $\mathrm{Bu}$ iki farklı ortamda çalışacak antenlerin tasarımı FR4 taban malzemesi üzerine yapılmıştır. FR4 kullanılmasının en önemli sebebi düşük maliyetli ve kolay bulunabilir olmasıdır. $\mathrm{Bu}$ malzemenin dielektrik sabiti $\varepsilon_{r}=3,45$, kayıp tanjantı $\tan \delta=0,057$ 'dir. Önerilen G-şeklinde katlanmış mikroşerit dipol anten ayrık portla beslenmiștir. Tasarım 1 ve Tasarım 2.' ye ait nihai anten uzunluk değerleri Tablo 2.' de gösterilmiştir.

Tablo 2. İmplant antenlerin uzunluk parametreleri

\begin{tabular}{ccc}
\hline Parametre Değişkeni & $\begin{array}{c}\text { Tasarım 1 } \\
{[\mathbf{m m}]}\end{array}$ & $\begin{array}{c}\text { Tasarım 2 } \\
{[\mathbf{m m}]}\end{array}$ \\
\hline$X$ & 34 & 28 \\
$X 1$ & 9,6 & 7,6 \\
$X 2$ & 5 & 3,4 \\
$X 3$ & 3,2 & 1,6 \\
$Y$ & 12 & 9,15 \\
$Y 1$ & 11 & 8,1 \\
$Y 2$ & 6,8 & 4,96 \\
$Y 3$ & 2,7 & 2,1 \\
$d$ & 1,3 & 1,2 \\
$w$ & 2,8 & 2,5 \\
$s$ & 2,6 & 2,6 \\
$T$ & 1,48 & 1,48 \\
$t \_m e t$ & 0,035 & 0,035 \\
\hline
\end{tabular}

Tablo 2.' de verilen, Tasarım 1 ve Tasarım 2 boyutları $X, Y$ ve $T^{\prime}$ ye bağlı olarak sırasıyla $34 \times 12 \times 1,48 \mathrm{~mm}^{3}$ ve $28 \times 9,15 \times 1,48 \mathrm{~mm}^{3}$ bulunmuştur. Şekil 7.' ye bakıldığında bu boyutların gerçek implant üzerine yerleştirilebilir ölçülerde olduğu görülebilir.

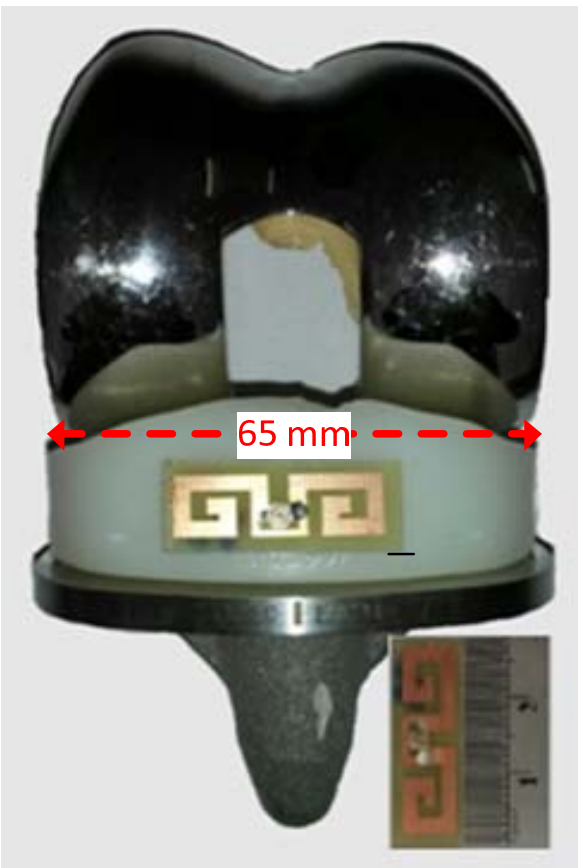

Şekil 7. Gerçek diz implantına uygulanabilir boyutlarda tasarlanmış etiket antenin yerleşimi

Hat kalınlığı $s$ ile ifade edilmiş olup her iki tasarımda da aynı değere sahiptir. Taban malzemesi üzerindeki metal kalınlığı $t \_m e t$ ile ifade edilmiş olup $0,035 \mathrm{~mm}$ kalınlığındadır. İletken yüzey ve taban malzemesinin oluşturduğu toplam kalınlık ise $T$ ile ifade edilmiş ve $1,48 \mathrm{~mm}$ olarak ölçülmüştür. $X 1, X 2, X 3$ ve $Y 1, Y 2, Y 3$ ışımanın gerçekleştiği dipol kolların uzunluklarını göstermektedir. Bu uzunluklardaki değișime göre 
çalışma frekansını ayarlamak ve böylece implant üzerine yerleștirilebilir boyutlarda bir anten tasarlamak mümkündür. Tasarım 1 ve Tasarım 2 için aynı çalışma frekansında $X, Y^{\prime}$ nin uzunluk değerleri farklıdır. Bunun sebebi antenlerin bulunduğu çalışma ortamıdır. Ortamın çalışma frekansı üzerindeki etkisi $X 1, X 2, X 3, Y 1, Y 2, Y 3$ 'e ait uzunluk parametrelerinde yapılan değişikliklerle azaltılmıştır. Besleme noktalarının (A ve B) hemen altında bulunan ve bükülmüş iki kolu birbirine kısa devre yapan şerit yapının genişliğini gösteren, $d$ ve $w$ ile ifade edilen yarık, empedans uyumlandırmada ve iyileștirilmiș geri dönüş kaybında ayar olarak kullanılmaktadır [25]. Ayrıca $d$ değerindeki artış dipol kolların mesafesini azaltacağı için istenilen merkez frekansının artmasına sebep olacaktır.

Antenin beslemesi merkezi iletkeni olan ve dış kılıfa sahip $50 \Omega$ koaksiyel kablo ile A ve B noktalarından yapılmıştır. Anten simetrik bir yapıya sahip olduğu için A ve B besleme uçları iki farklı șekilde seçilebilir [23]. Besleme noktasında 3x3,1 mm boyutlu U.PL IPX tipi yüzey montaj teknolojili koaksiyel konnektör kullanılmıştır. Antenin uygun ortama taşınabilmesi ve ölçülebilmesi için beslemede kullanılan konnektöre IPX/U.FL tip dönüştürücü özelliği olan RF kablo takılmıştır. Şekil 8.' de baskı devresi yapılan antenler, besleme yapılan port ve bağlantı șekli verilmiștir.

Șekil 8.' de gösterilen antenlerin, tasarım simülasyonları CST Microwave Studio ve ölçümleri Agilent marka N9926A model Network Analizör ile yapılmıştır. Tasarlanan iki antenden, doku içerisindeki implanta takılabilir olanı (Tasarım 1) için geri dönüş kaybı simülasyon sonucu ile vücut dışında çalışması planlanan antenin (Tasarım 2) simülasyon ve ölçüm sonuçları karşılaştırmalı olarak Şekil 9.' da sunulmuştur.

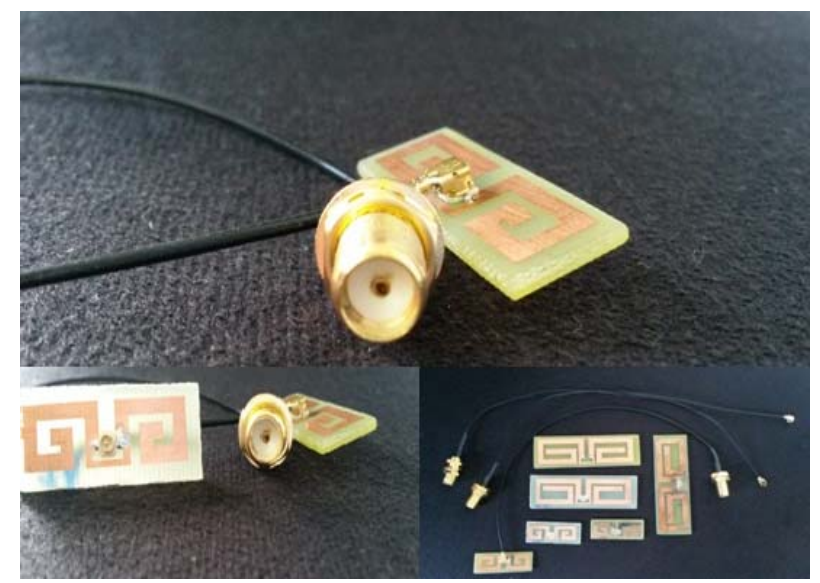

Şekil 8. Baskı devre yapılan RFID etiket anteni ve konnektör bağlantıları

Şekil 9.' da Tasarım 1 ve Tasarım 2' ye ait ölçüm ve simülasyon sonuçları Tablo 3.' de ayrıntılı olarak gösterilmektedir. Tasarım 1'in anteni 2,45GHz'de $49 \mathrm{~dB}$ geri dönüş kaybı ile rezonansa gelmiş, 10dB'nin altında $260 \mathrm{MHz}$ bir bant genişliğine frekansında, $-46 \mathrm{~dB}$ geri dönüş kaybı ve $100 \mathrm{MHz}$ bant genişliğine sahiptir. Aynı anten için ölçüm sonuçlarına bakıldığında $2,47 \mathrm{GHz}$ merkez frekansında $-30 \mathrm{~dB}$ geri dönüș kaybı ve $98 \mathrm{MHz}$ bant genişliğinin olduğu gözükmektedir. RFID sistemlerde UHF bandında $2 \mathrm{MHz}$ 'lik bir bant genişliği yeterli olmaktadır [28]. Bu veri ışığında Tasarım 1 ve Tasarım 2'ye ait bant genișliklerinin yeterli olduğu anlașılmaktadır.

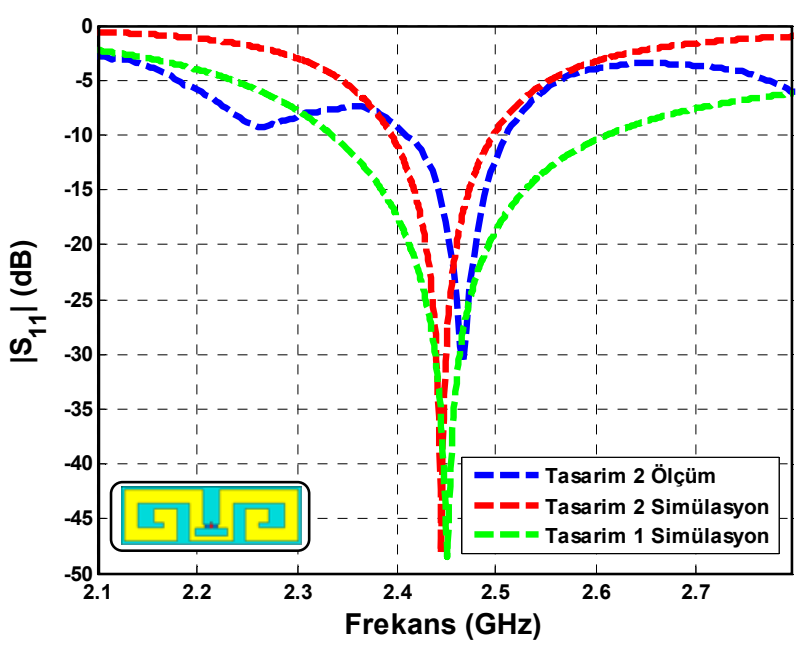

Şekil 9. Tasarım 1 ve Tasarım 2' ye ait $\left|S_{11}\right|$ karakteristiği

Şekil 10.' da Tasarım 1' e ait E-düzlemi ve Hdüzlemini gösteren ışıma örüntüsü kazanç grafiği gösterilmektedir. Bu grafiğe göre maksimum kazanç $0,103 \mathrm{~dB}^{\prime}$ dir.

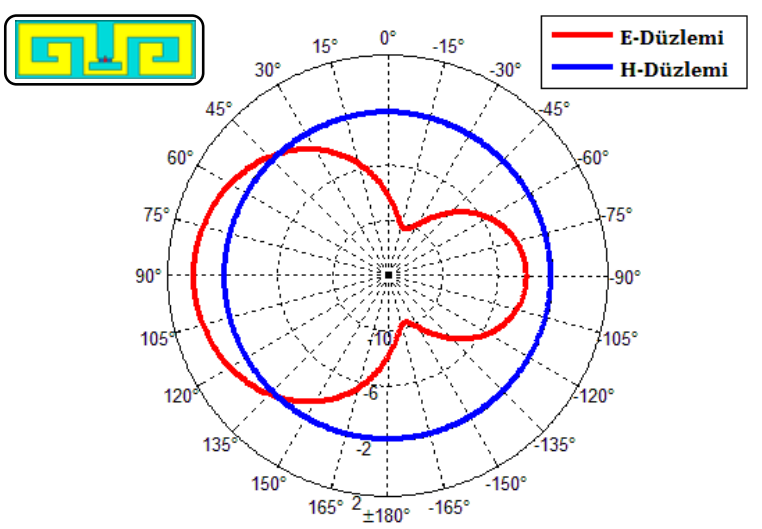

Şekil 10. Tasarım 1'e ait ışıma örüntüsü kazanç grafiği

Şekil 11.' de Tasarım 2' ye ait E-düzlemi ve $\mathrm{H}$ düzlemini gösteren ışıma örüntüsü kazanç grafiği gösterilmektedir. Bu grafiğe göre maksimum kazanç 1,22dB'dir.

Tablo 3.' e göre Tasarım 1' e ait antenin, Tasarım 2' ye ait antene göre kazancının azaldığı bant genișliğinin arttığı gözlenmektedir. Bu durumun deri dokusu ve polietilen malzemenin Tasarım 1' e ait anten üzerindeki etkilerini göstermektedir.

Tablo 4.' de literatürde bulunan implanta yerleştirilmiş RFID etiket antenlerin çalışma frekansı, anten boyutları, antenin yerleştirildiği konum ve geri 
dönüş kaybına göre karşılaştırılması verilmiştir. Bu tablodan özetle, mevcut RFID etiket antenlere göre bu çalışmada tasarlanan antenin geometrik yapısının daha küçük olarak mikrodalga frekanslarda tasarlanabildiği ve daha iyi geri dönüş kaybına sahip olduğu önemli bir yenilik olarak görülmektedir. Böylece, G-şeklinde katlanmış mikroşerit dipol anten geometrisi ile daha küçük implantlar için daha küçük ve uygulanabilir RFID etiket anteni tasarımına kapı açılmıştır.

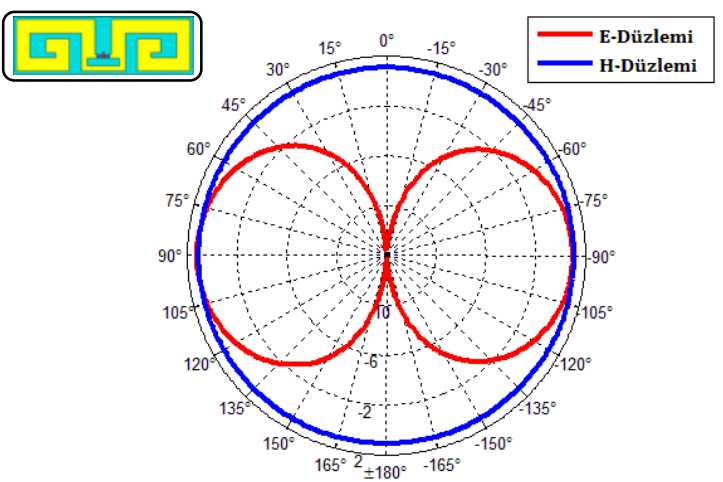

Şekil 11. Tasarım 2' ye ait ışıma örüntüsü kazanç grafiği

Tablo 3. Tasarım 1 ve 2' ye ait anten modellerinin kazanç, $\left|S_{11}\right|$ ve bant genișliğine göre karșılaștırılması

\begin{tabular}{ccccc} 
ANTENLER & $\begin{array}{c}\text { Kazanç } \\
{[\mathbf{d B}]}\end{array}$ & $\begin{array}{c}\left|\mathbf{S}_{\mathbf{1 1}}\right| \\
{[\mathbf{d B}]}\end{array}$ & $\begin{array}{c}\text { Bant Genişliği } \\
{[\mathbf{M H z}]}\end{array}$ \\
\hline \multirow{2}{*}{$\mathbf{N}$} & Simülasyon & 0,103 & -49 & 260 \\
& Ölçüm & - & - & - \\
& & & & \\
& Ölçülasyon & 1,22 & -46 & 100 \\
& & - & -30 & 98
\end{tabular}

Tablo 4. İmplant tanımlama için yapılmış mevcut çalıșmalardaki RFID etiket antenlerin karșılaștırılması

\begin{tabular}{ccccc}
$\begin{array}{c}\text { Referans } \\
\text { No }\end{array}$ & $\begin{array}{c}\text { Çalışma } \\
\text { Frekansi } \\
{[\mathbf{M H z}]}\end{array}$ & $\begin{array}{c}\text { Anten } \\
\text { Boyutları } \\
{\left[\mathbf{m m}^{2}\right]}\end{array}$ & $\begin{array}{c}\text { Antenin } \\
\text { Konumu }\end{array}$ & $\begin{array}{c}\left|\mathbf{S}_{\mathbf{1 1}}\right| \\
{[\mathbf{d B}]}\end{array}$ \\
\hline $\mathbf{8}]$ & 13,56 & $30 \times 10$ & $\begin{array}{c}\text { Metal } \\
\text { yüzey }\end{array}$ & -40 \\
$\mathbf{[ 1 4 ]}$ & 13,56 & - & $\begin{array}{c}\text { Metal } \\
\text { yüzey }\end{array}$ & - \\
$\mathbf{[ 1 6 ]}$ & 915 & $50 \times 15$ & $\begin{array}{c}\text { Metal } \\
\text { yüzey }\end{array}$ & - \\
$\mathbf{[ 2 9 ]}$ & 13,56 & $30 \times 10$ & $\begin{array}{c}\text { Metal } \\
\text { yüzey }\end{array}$ & - \\
$\begin{array}{c}\text { Bu } \\
\text { Çalışma }\end{array}$ & 2450 & $28 \times 9,15$ & $\begin{array}{c}\text { Polietilen } \\
\text { Yüzey }\end{array}$ & -46 \\
\hline
\end{tabular}

\section{Tartışma ve Sonuç}

$\mathrm{Bu}$ çalışma kapsamında diz implantına yerleştirilebilen RFID etiket için anten tasarımı ve gerçeklemesi hedeflenmişti. Doku ve boş uzay ortamında, iki adet G-şeklinde katlanmış mikroşerit dipol anten tasarımları simüle edilmiş, baskı devre edilip ölçülmüş ve sonuçlar karşılaştırmalı olarak irdelenmiştir. Antenlerin implant ortamındaki performanslarını görebilmek için geri dönüş kaybı, bant genişliği, kazanç ve ışıma örüntüleri incelenmiştir. Geometrik boyutuna bakıldığında elde edilen antenlerin gerçek implanta monte edilebileceği görülmüştür. Ayrıca, geri dönüş kaybı, bant genişliği ve kazanç değerlerinin mikrodalga frekanslı RFID sistemlerinde veri haberleşmesi için yeterli olduğu tespit edilmiştir.

Sonraki çalışmalarda, deney canlıları ile yapılan denemelere yüksek benzerlik gösteren fantom ortamlarda tasarlanan RFID etiketli implantın anten ölçümlerinin gerçekleştirilmesi planlanmaktadır. Doku içi ölçümler yapılmadan önce gerekli kimyasallarla fantom ortamlar hazırlanıp anten veya RFID etiket performansına bakılacaktır. Bu ölçümlerde biyo-uyumlu malzemelerin etkisi, ortopedik implantların etiket antenine etkisi gibi etkenlerin anten performansını nasıl değiștirebileceği izlenecektir.

\section{Teşekkür}

$\mathrm{Bu}$ çalışma Süleyman Demirel Üniversitesi Bilimsel Araştırma Projeleri Yönetim Birimi Başkanlığınca 4256-YL1-15 No' lu ve "İmplant Tanımlama İçin RFID Sistem Tasarımı" başlıklı proje ile desteklenmiştir.

\section{Kaynakça}

[1] S. Kurtz, K. Ong, E. Lau, F. Mowat, and M. Halpern, "Projections of primary and revision hip and knee arthroplasty in the United States from 2005 to 2030," The Journal of Bone \& Joint Surgery, vol. 89, pp. 780-785, 2007.

[2] R. Want, "An introduction to RFID technology," Pervasive Computing, IEEE, vol. 5, pp. 25-33, 2006.

[3] K. Finkelzeller, "The RFID handbook," ed: John Wiley \& Sons, 2003.

[4] S. Hu, C. L. Law, and W. Dou, "A balloon-shaped monopole antenna for passive UWB-RFID tag applications," Antennas and Wireless Propagation Letters, IEEE, vol. 7, pp. 366-368, 2008.

[5] D. Brown, RFID implementation: McGraw-Hill, Inc., 2006.

[6] A. Ogirala, J. R. Stachel, P. J. Hawrylak, D. Rong, R. K. Yalamanchili, M. A. Rothfuss, X. Liu, S. Saba, and M. H. Mickle, "Impact of ISO 18000 series RF signals on CRMDs: a unified approach," International Journal of Modelling and Simulation, vol. 31, p. 250, 2011.

[7] U.-M. Jow and M. Ghovanloo, "Design and optimization of printed spiral coils for efficient transcutaneous inductive power transmission," Biomedical Circuits and Systems, IEEE Transactions on, vol. 1, pp. 193-202, 2007. 
[8] X. Liu, J. L. Berger, A. Ogirala, and M. H. Mickle, "A touch probe method of operating an implantable RFID tag for orthopedic implant identification," Biomedical Circuits and Systems, IEEE Transactions on, vol. 7, pp. 236-242, 2013.

[9] C. Occhiuzzi and G. Marrocco, "Human body sensing: A pervasive approach by implanted RFID tags," in Applied Sciences in Biomedical and Communication Technologies (ISABEL), 2010 3rd International Symposium on, 2010, pp. 1-5.

[10] P. Foster and R. Burberry, "Antenna problems in RFID systems," 1999.

[11] X. Qing and Z. N. Chen, "Proximity effects of metallic environments on high frequency RFID reader antenna: Study and applications," Antennas and Propagation, IEEE Transactions on, vol. 55, pp. 3105-3111, 2007.

[12] D. M. Dobkin, The RF in RFID: UHF RFID in Practice: Newnes, 2012.

[13] R. Bashirullah, "Wireless implants," Microwave Magazine, IEEE, vol. 11, pp. S14-S23, 2010.

[14] X. Liu, A. Ogirala, L. Berger, and M. Mickle, "Design and implementation of a volume conduction based RFID system for smart implants," in 2011 Annual International Conference of the IEEE Engineering in Medicine and Biology Society, 2011, pp. 2893-2896.

[15] X. Liu, R. Yalamanchili, A. Ogirala, and M. Mickle, "An alternative approach of operating a passive RFID device embedded on metallic implants," in Wireless and Microwave Technology Conference (WAMICON), 2011 IEEE 12th Annual, 2011, pp. 16.

[16] X. Liu, J. R. Stachel, E. Sejdic, M. H. Mickle, and J. L. Berger, "The UHF Gen 2 RFID System for transcutaenous operation for orthopedic implants," in 2013 IEEE International Instrumentation and Measurement Technology Conference (I2MTC), 2013, pp. 1620-1623.

[17] "Kısa Mesafe Erişimli Telsiz (KET) Cihazları Hakkında Yönetmelik," ed: RESMİ GAZETE, 11 Eylül 2012 Salı.

[18] BTK, Bilgi Teknolojileri ve İletișimi Kurumu, Milli Frekans Planı ve Diğer Planlar. Available: https://ifis.btk.gov.tr/wmfys/millifrekanssorgu. aspx(Erişim Tarihi: 15.02.2016).

[19] K. S. Rao, P. V. Nikitin, and S. F. Lam, "Antenna design for UHF RFID tags: a review and a practical application," Antennas and Propagation, IEEE Transactions on, vol. 53, pp. 3870-3876, 2005.

[20] D. M. Dobkin and S. M. Weigand, "Environmental effects on RFID tag antennas," in Microwave Symposium Digest, 2005 IEEE MTT-S International, 2005, p. 4 pp.
[21] P. V. Nikitin, S. Lam, and K. Rao, "Low cost silver ink RFID tag antennas," in Antennas and Propagation Society International Symposium, 2005 IEEE, 2005, pp. 353-356.

[22] D. M. Pozar, Microwave engineering: John Wiley \& Sons, 2009.

[23] X. Li, L. Yang, S.-X. Gong, Y.-J. Yang, and J.-F. Liu, "A compact folded printed dipole antenna for UHF RFID reader," Progress In Electromagnetics Research Letters, vol. 6, pp. 47-54, 2009.

[24] S. W. Su and J. H. Chou, "Compact coaxial-line-fed flat-plate dipole antenna for WLAN applications," Microwave and Optical Technology Letters, vol. 50, pp. 420-422, 2008.

[25] K. B. U. Depok, "Compact Folded Dipole Microstrip Antenna for $2.4 \mathrm{GHz}$ WLAN Application."

[26] Y. Özalp and N. Özdemir, "Biyomateryaller ve Biyouyumluluk," Ankara Üniversitesi Eczacılık Fakültesi Dergisi, vol. 25, pp. 57-72, 1996.

[27] E. Postow and C. Polk, Handbook of biological effects of electromagnetic fields: Boca Raton: CRC Press, 1996.

[28] A. Kavas, "Radyo Frekans Tanımlama Sistemleri," Elektrik Mühendisliği Dergisi, pp. 74-80, 2007.

[29] X. Liu, R. Yalamanchili, A. Ogirala, and M. Mickle, "A Volume Conduction Approach to Operate a Passive RFID Tag on Metallic Implants." 